seems to confirm in every particular the conclusions arrived at by Sir James 'Barr, Dr. W. Blair Bell, and Captain S. R. Douglas, I.M.S.,, in their report in THE LANCET of Feb. 23rd last, of the first case of streptococcic septicæmia that had been successfully treated by means of a vaccine prepared and controlled by Sir A. E. Wright's method.

In conclusion, we wish to acknowledge our indebtedness to Dr. Charles Slater, bacteriologist to St. George's Hospital, for his kindness in placing the resources of his laboratory at our disposal.

Margate.

\section{Clinital 望otes:}

\section{MEDICAL, SURGICAL, OBSTETRICAL, AND THERAPEUTICAL.}

\section{POLYDACTYLISM.}

By William J. MoRRISh, M.D. Lond., L.R.C.P. LoNd., M.R.C.S. ENG.

REFERRING to Dr. W. H. W. Attlee's case of supernumerary digits, published in THE LANCET of July 20th, p. 163, I may perhaps record the following.

On Nov. 29th, 1906, I attended a woman in her seventh confinement, the child proving to be a girl. She had previously had two boys and four girls. Both boys were normal, but the girls presented the following peculiarities as regards their hands and feet. Each child had six digits on both hands, the additional digit being situated on the ulnar side, and in the case of the three eldest having bony union with the rest of the hand; while in the two youngest the additional finger was attached by a pedicle of skin and vessels as in Dr. Attlee's case. The mother had had the sixth fingers removed from the first and second girls, but on account of her delicacy the hands of the third had not been operated on and I was thus able to see the extra members. On the right hand the finger possessed a metacarpal bone which was in relation with the carpus, but on the left side the digit was very rudimentary, though having bony connexion with the ulnar side of the little finger. The pedunculated sixth fingers of the fourth and fifth girls were removed after ligaturing their pedicles. The middle and ring fingers of the eldest girl's left hand were also webbed throughout their entire length. Their feet showed even greater variation. The eldest girl had six toes on her left but only five on her right foot, with webbing of the great, second, and third toes of both feet. The second had five toes, with slight webbing of the second and third on each foot. The third had six, with the second and third completely webbed on each foot. The fourth girl presented the greatest abnormality of any, having an apparently spatulate condition of each great toe, which on closer examination gave the appearance of a fusion of two separate toes, while in addition to this on the right foot there were two little toes apparently in relation with the fifth metatarsal, the remaining digits of the left foot being normal. The only abnormality of the feet of the newly-born fifth girl was a very slight degree of webbing of the second and third toes of each side. The father of these children had six digits on each hand and foot, with bilateral webbing of the second and third toes. He was an only child and his father and mother were quite normal as regards their hands and feet. He was not related to his wife prior to their marriage.

This remarkable case is another example of the well established fact of the hereditary tendency of this sort of deformity, and it is noticeable that the male children should have escaped.

Streatham, S.W.

NOTE ON A CASE OF BELLADONNA POISONING. By H. JeAFFreson BreWer, L.R.C.P. LoND., M.R.C.S. ENG.

IT is said that children are able to take belladonna well and do not suffer from any toxic effects, and on looking through Woodman and Tidy's "Toxicology" the only cases of poisoning in children were caused by taking large quantities of the berries. From this point of view I think the following case of what was obviously belladonna poisoning may be of interest.

To a boy, aged four years and three months, suffering from whooping cough, I prescribed two minims of tincture of belladonna and two grains of bromide of potassium, to be taken every four hours. Within half an hour of the administration of the first dose, the mother told me, a red flush came out round the child's neck and on his chest. The mouth seemed dried up and the child was slightly delirious, but in about an hour he got much better. A second dose of the mixture was given four hours after the first, and again in half an hour the child suffered in the same way and was violently sick. Then I was sent for. On arrival I found the child almost covered with a scarlatiniform rash, chiefly on the neck and chest; the pulse was rapid (120) and very feeble ; the mouth was dry ; the pupils were fully dilated, a narrow ring of the iris only being visible; and the temperature was slightly raised $\left(100^{\circ} \mathrm{F}\right.$.). The child was only semi-conscious and was with difficulty roused and could not speak. On administering brandy consciousness and speech returned, the pulse slowed, and the pupils began to contract. When I saw the child on the next morning he had quite recovered, except for a very faint rash which entirely disappeared within 24 hours.

Considering the very small dose administered I think this idiosyncrasy worth recording.

Dalston, N.E.

\section{NOTE ON THE FFFECTS OF BORAX ON INFANTS.}

By James Charles MoWalter, M.D. Brux., L.R.C.S. IREL., D.P.H.

THE question of the propriety of employing borax or other compounds as a preservative for milk or other foods is one which cannot be decided by the mere obiter dicta of the medical man. Powerful commercial influences are concerned in the use of preservatives in food and it is not sufficient for a medical man absolutely to condemn the practice if he finds himself in the witness box under the examination of an able King's counsel. This gentlemen will doubtless demand specific instances of the harmful effects, either from the witness's experiences or from credible works. These instances seem to be particularly scanty in British journals, although Dr. Wyley has done a lot of work on the subject in America. I wish, then, to record a case of chronic borax poisoning which is just now under my care and which seems as conclusive of the evil effects of the drug as a single instance can possibly be, for in this case the mother suckled the infant all the time and gave it no other nourishment.

The infant was two months old when $I$ saw it and had been born a strong, healthy child. A fortnight after birth it developed thrush, for which borax and honey were applied. The child seemed to be relieved of the thrush by this remedy and developed such a liking for it that it was applied most liberally-from two to three four-drachm boxes having been used every week from the second to the eighth week. During this time a progressive wasting had set in, and when I saw the infant there was a marked erythematous eruption on the palmar aspect of the hands and on the plantar aspect of the feet, with distinct desquamation between the toes and the fingers; well-marked urticarial eruption was present on the arms and forearms, but the region between the legs was notably free from eruption. There were tumefaction and tenderness of the abdomen, and a raw, pinky redness of the lips, tongue, palate, and throat, with vomiting and looseness of the bowels. The face had a wizened look, the skin was soft and brownish, the eyes were bright, and the joints, especially the knees, tender, swollen, and somewhat stiff. There was no evidence of syphilis or other cause for the wasting and rash except the borax, of which the child had about ten grains every day for six weeks. On stopping the borax and confining the infant to the breast milk, together with a little raw beef-juice, it appears to be recovering rapidly.

Dublin.

"Miner's Phthisis."-At a recent meeting of the Redruth (Cornwall) board of guardians the Local Government Board inspector (Mr. J. Preston Thomas) referred to "miner's phthisis" and its effect on the pauperism of the union. He mentioned that nearly 350 cases of pauperism were due directly to this disease, or about one-quarter of the whole pauperism in the Redruth union. 